\title{
OOROIASIO0
}

Available online at Website http://ejournal.undip.ac.id/index.php/rotas

\section{RANCANG BANGUN ALAT UJI RUNNING-IN UNTUK SISTEM KONTAK TWO-DISC}

\author{
*Petrus Londa, Taufiq Hidayat, Nana Supriyana, Jamari, Sri Nugroho \\ Program Studi Magister Teknik Mesin, Fakultas Teknik, Universitas Diponegoro \\ Jl. Prof. Sudharto, SH., Tembalang-Semarang 50275, Telp. +62247460059 \\ *E-mail: PetrusLonda@yahoo.com
}

\begin{abstract}
ABSTRAK
Keausan merupakan fenomena tribologi yang terjadi pada setiap peralatan akibat kontak mekanik antara dua komponen. Dalam kurun waktu yang lama keausan ini akan menimbulkan kerusakan pada peralatan. Untuk meningkatkan keandalan dan efisiensi peralatan, maka fenomena keausan ini perlu dikaji lebih lanjut. Didalam ilmu tribology para peneliti membagi proses terjadinya keausan akibat kontak mekanik tersebut menjadi tiga fase, yaitu fase running-in, fase steady state (fase tunak) dan fase wear-uot. Untuk mengetahui secara cepat kondisi dari ketiga fase tersebut diperlukan alat uji running-in.

Paper ini difokuskan pada rancang bangun alat uji running-in. Alat ini dipakai untuk menguji komponen yang terdiri dari dua buah piringan (two-disc) yang terbuat dari material yang dapat divariasikan jenisnya. Perancangan mekanismenya memungkinkan sisi kedua piringan pada arah radial saling kontak ketika kedua piringan tersebut berputar (rolling contact) dan dapat divariasikan beban maupun putaran. Untuk itu metode perancangan Pugh dapat memberikan solusi, karena dengan metode ini semua konsep produk akan dinilai dan konsep produk terbaik yang akan dikembangkan menjadi produk.

Pengujian dilakukan secara eksperimen untuk mengetahui fenomena keausan yang terjadi mulai dari kondisi running-in sampai kondisi steady state. Hasil rancangan menunjukan bahwa alat uji dapat digunakan untuk menentukan variabel-variabel dalam proses running-in. Dengan variasi jumlah putaran (maksimal $2800 \mathrm{rpm}$ ), beban tekan (masimal $5 \mathrm{~kg}$ ) dan beban torsi yang dapat dikontrol $(5 \mathrm{~kg})$ serta arah putaran specimen yang dapat diatur, maka gaya gesek pada permukaan specimen dapat diketahui, sedangkan variabel yang diukur adalah perubahan kekasaran permukaan.
\end{abstract}

Kata kunci: perancangan, rolling contact, running-in, steady state twin-disc.

\section{PENDAHULUAN}

Hampir semua alat-alat mekanik, mengalami kontak mekanik pada permukaan ketika sedang dalam kondisi kerja. Kontak yang terjadi antara komponen bisa berupa static contact, rolling contact, atau sliding contact, misalnya kontak yang terjadi antara ball dengan inner race dan outer race pada ball bearing, gesekan piston terhadap dinding silinder atau, gesekan camshaft dengan katup dalam motor bakar, dan lain sebagainya. Akibat dari kerja komponen tersebut maka akan timbul adanya pengikisan permukaan komponen atau sering disebut keausan (wear).

Tingkat pertumbuhan keausan ini dapat diketahui dengan metode yang akurat. Sebagai contoh, jika ingin mengetahui tingkat pertumbuhan keausan pada kontak antara roda gigi, maka pasangan roda gigi tersebut dioperasikan dalam kondisi yang sebenarnya dalam jangka waktu tertentu atau sampai kondisi dari sistim mengalami keausan. Kemudian pertumbuhan keausannya dihitung dengan mengukur perubahan geometri permukaan kontak yang terjadi. Geometri hasil pengukuran tersebut dibandingkan dengan geometri awal, sehingga didapat selisih nilai geometri. Selisih nilai geometri ini merupakan nilai keausan. Metode ini memang akurat namun memiliki beberapa kelemahan dipandang dari sisi biaya yang mahal dan waktu yang lama. Oleh karena itu tingkat pertumbuhan keausan ditentukan secara eksperimen yang lebih sederhana dengan menggunakan tribometer. Tribometer ini mencoba menirukan kondisi yang sebenarnya dengan menyamakan material dan permukaan kontak [1].

Tujuan dari penelitian ini adalah merancang dan membuat sebuah alat tribometer yang memungkinkan peneliti dapat mengatur beban tekan pada permukaan disc, arah putaran disc dan jumlah putaran dari masing-masing disc sehingga dapat diketahui nilai gaya gesek pada permukaan kontak. Dalam melakukan proses eksperimen, pengambilan data hasil eksperimen yaitu gaya gesek dan jumlah putaran terintegrasi dengan komputer dengan menggunakan program LabVIEW.

\section{MATERIAL DAN METODOLOGI}

\subsection{Tahap Perancangan Konsep Produk.}

Perancangan adalah suatu usaha kreatifitas untuk mewujudkan suatu produk. Ada beberapa fase yang harus dilalui dalam mewujudkan suatu produk, yaitu (1) fase defenisi proyek, perencanaan proyek dan penyusunan spesifikasi teknis produk, (2) fase perancangan konsep produk, (3) fase perancangan produk dan (4) fase penyusunan dokumen untuk pembuatan produk [2]. Ada beberapa metode yang dikembangkan untuk melewati fase-fase dalam perancangan 
sehingga produk dapat diwujudkan, pada fase pertama yaitu fase penyusunan spesifikasi teknis produk banyak metode yang dikembangkan seperti metode French, metode Pahl dan Beitz, metode VDI. metode Ullman dan metode QFD, sedangkan pada fase ke dua yaitu fase perancangan konsep produk dimana produk yang akan dihasilkan dibuatkan sebanyak mungkin konsepnya baik dalam bentuk gambar sketsa maupun dalam bentuk abstraksi. Semua konsep produk tersebut kemudian dievaluasi sehingga hanya satu konsep produk terbaik yang akan dikembangkan menjadi produk. Dalam mengevaluasi konsep produk ini ada beberapa metode yang digunakan, yaitu evaluasi konsep produk berdasarkan kelayakan dan evaluasi konsep produk berdasarkan jawaban Ya atau TIDAK, kedua jenis evaluasi ini dinamakan metode perbandingan absolut, sedangkan metode yang lain adalah metode Pugh dimana pada metode ini semua kriteria konsep produk dituangkan dalam sebuah matriks penilaian konsep produk. Konsep produk yang nilainya tertinggi yang akan dikembangkan menjadi produk. Dari sekian banyak metode yang digunakan, maka pada tahap perancangan ini metode yang digunakan untuk merancang produk pada penelitian ini adalah metode Pugh. Metode ini digunakan karena dipandang lebih sederhana dan lebih sesuai dengan kebutuhan pelanggan.

Metode Pugh atau yang lebih dikenal dengan metode matriks keputusan atau metode perbandingan relative adalah metode yang dikembangkan untuk membandingkan konsep produk yang telah dievaluasi pada metode sebelumnya yaitu metode perbandingan absolut. Tabel berikut ini adalah matriks keputusan dari 4 buah konsep produk alat uji running-in yang telah dievaluasi pada metode sebelumnya. Dalam tabel tersebut dapat dilihat bahwa konsep produk (K-IV) adalah konsep produk terpilih yang akan dikembangkan menjadi produk.

Tabel 1. Matriks keputusan untuk memilih konsep produk

\begin{tabular}{|c|c|c|c|c|c|c|}
\hline No. & Kriteria & $\mathbf{W t}$ & K - I & $\mathbf{K}-\mathbf{I I}$ & K - III & K - IV \\
\hline 1 & Putaran motor bisa diatur & 10 & 10 & 10 & 10 & 10 \\
\hline 2 & Putaran specimen bisa di kontrol & 10 & 10 & 10 & 10 & 10 \\
\hline 3 & Putaran specimen masing-masing bisa berbeda & 10 & 10 & 10 & 10 & 10 \\
\hline 4 & Fleksibilitas ukuran specimen & 8 & 4 & 4 & 2 & 8 \\
\hline 5 & Pengaturan beban tekan & 10 & 8 & 8 & 4 & 7 \\
\hline 6 & Pengaturan beban torsi & 10 & 5 & 5 & 5 & 9 \\
\hline 7 & Antisipasi poros bending & 9 & 5 & 5 & 9 & 8 \\
\hline 8 & Antisipasi slip & 9 & 4 & 8 & 8 & 8 \\
\hline 9 & Kecepatan penggantian specimen & 6 & 5 & 5 & 2 & 5 \\
\hline 10 & Bisa digunakan untuk pengujian disc & 10 & 10 & 10 & 10 & 10 \\
\hline 11 & Sistem pelumasan & 6 & 2 & 2 & 2 & 2 \\
\hline 12 & Mudah dalam pengoperasian & 7 & 5 & 5 & 5 & 5 \\
\hline 13 & Biaya pembuatan murah & 6 & 3 & 3 & 3 & 3 \\
\hline 14 & Ergonomis & 8 & 2 & 2 & 2 & 3 \\
\hline 15 & Dimensi alat ringkas dan praktis & 8 & 2 & 2 & 2 & 4 \\
\hline 16 & Terdapat sensor-sensor & 10 & 10 & 10 & 10 & 10 \\
\hline 17 & Mudah dalam pembuatan & 9 & 3 & 3 & 3 & 7 \\
\hline 18 & Mudah dalam pemeliharaan & 7 & 7 & 7 & 7 & 7 \\
\hline & Jumlah & 153 & 105 & 109 & 104 & 126 \\
\hline
\end{tabular}

Keterangan: $\quad \mathrm{K}=$ Konsep produk.

$\mathrm{Wt}=$ Bobot nilai maksimum

2.2. Alat dan Bahan Penelitian.

Alat dan bahan yang digunakan dalam penelitian ini meliputi:

a. Hardware:

Dua buah motor AC 3 phasa, $1 \mathrm{Hp}$.

Personal computer.

DAQPAD 6020E (BNC).

Timbangan.

Tachometer.

Dua buah Reflective Optic Sensor (ROS), 12 Volt DC, PNP output.

Dua buah regulator tegangan: TL 7805, 5 Volt output, 1 Ampere.

Amplifier: OP-Amp TL 078, 4 channel, adjust gain.

Switching regulator: $12 \mathrm{~V}, 2$ Ampere.

Dua buah Peraga RPM: 4 digit seven segment.

Load cell: Max. load $5 \mathrm{~kg}$.

Peraga beban: 4 digit seven segment.

Kabel: 4 wired, 4 color, diameter 0,4 $\mathrm{mm}$ dan 1,5 $\mathrm{mm}$.

Variable Frequency Drive (VFD/Inverter), 3 phasa, 1,5 Hp.

Material dan peralatan untuk pembuatan konstruksi mesin.

b. Software: Program LabVIEW. 
2.3. Tahapan Perancangan Produk.

Prosedur penelitian pada tahapan perancangan produk meliputi perancangan produk, pembuatan mesin tribometer, kalibrasi dan pengujian.

\subsubsection{Perancangan Produk.}

Pada tahapan perancangan produk, sistem dibagi menjadi:

a. Perancangan sistem mekanisme tribometer.

Perancangan sistem mekanisme dilakukan berdasarkan fungsi utama dari mesin tribometer yaitu menguji pasangan disc untuk memperoleh koefisien gesek.

b. Perancangan sistem pembacaan RPM.

c. Perancangan sistem pembacaan beban.

d. Perancangan sistem dispay.

e. Perancangan sistem beban tekan dan rem.

Skema rancangan secara lengkap dapat dilihat pada Gambar 1 berikut ini.

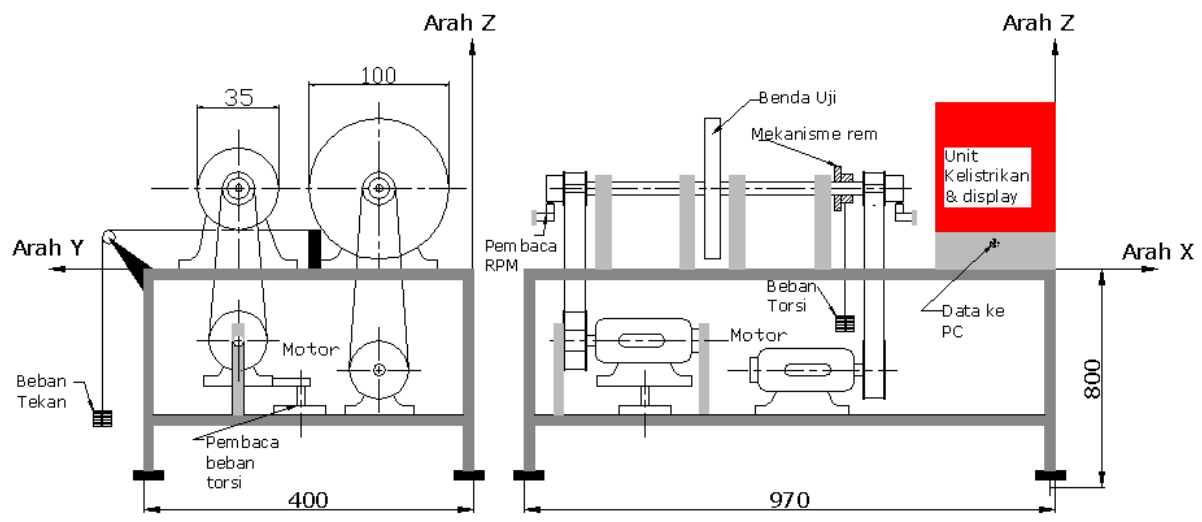

Gambar 1. Skema rancangan mesin tribometer

\subsubsection{Pembuatan Mesin Tribometer.}

Pada tahap pembuatan sistem mekanisme, putaran poros specimen menggunakan transmisi sabuk bergigi (timing belt), sistem ini digunakan agar slip pada poros sekecil mungkin dan menghindari kebisingan [3]. Pada pembuatan mekanisme beban tekan menggunakan sistem katrol dan linear bearing sehingga memungkinkan specimen pada poros sebelah kanan dapat bergerak maju dan menekan specimen yang lainnya. Sedangkan sistem pembacaan RPM menggunakan Reflective Optic Sensor dan sistem pembacaan beban akibat torsi menggunakan load cell seperti ditunjukan pada gambar 2 (a) dan (b), masing-masing melalui regulator yang dihubungkan pada sebuah amplifier. Untuk mengatur jumlah putaran dan arah putaran poros specimen menggunakan Variable Frequency Drive (VFD/Inverter). Dari hasil pembacaan tersebut masing-masing ditampilkan pada mesin melalui peraga (seven segment), selain itu hasil pembacaan juga dikirim ke unit Personal Computer melalui DAQPAD. Data dari mesin ini dibaca menggunakan program LabVIEW, pemilihan bahasa pemrograman ini didasarkan pada keunggulan yang dimiliki, antara lain bahasa pemrograman ini dibuat dalam bentuk blok diagram atau yang dikenal dengan nama " $G$ ", sehingga menghindari kesalahan ketik seperti titik, koma, tanda seru dan lain-lain [4]. Sesaat setelah data dapat terbaca dan ditampilkan, maka dilakukan kalibrasi terhadap beban dan jumlah putaran. Kalibrasi ini dimaksudkan agar data yang terbaca dapat sesuai dengan alat ukur yang standar, kalibrasi untuk RPM menggunakan tachometer dan untuk beban menggunakan timbangan. Hasil kalibrasi kedua alat tersebut menunjukan tingkat kepercayaan yang sangat tinggi, yaitu 99\% seperti yang ditampilkan pada gambar 3 (a) untuk kalibrasi load cell dan gambar 3 (b) untuk kalibrasi putaran poros.

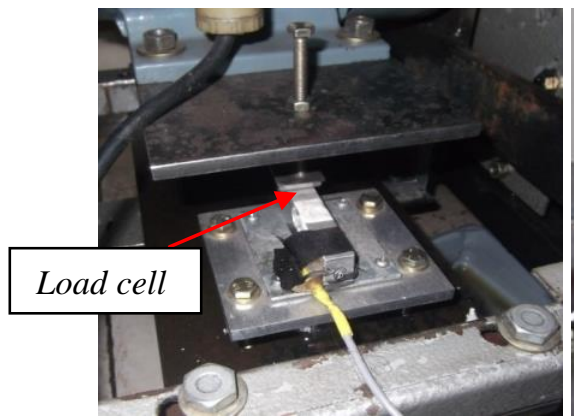

(a)

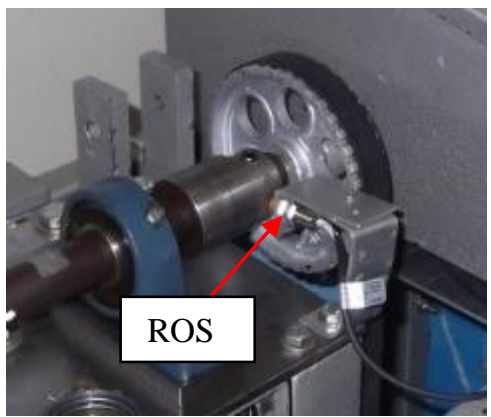

(b)

Gambar 2. Load cell dan Reflective Optic Sensor (ROS) 


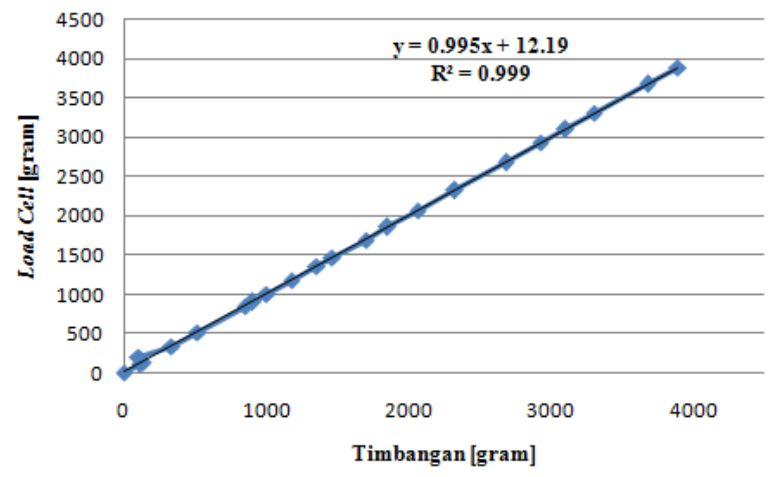

(a)

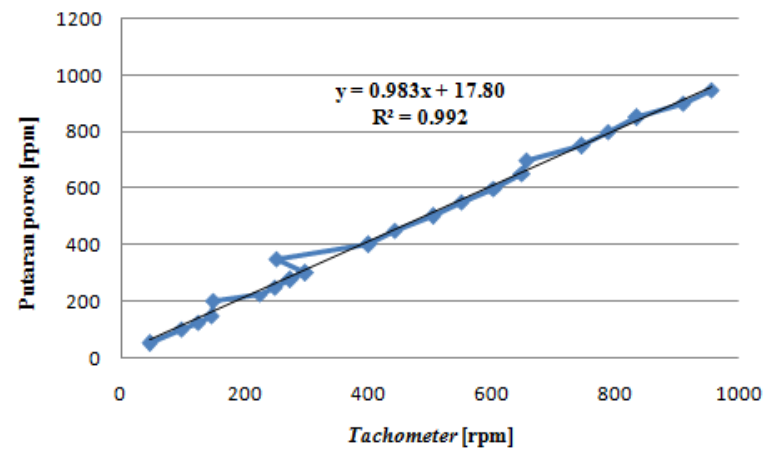

(b)

Gambar 3. Hasil kalibrasi putaran dan beban

\subsubsection{Pengujian Mesin Tribometer.}

Pengujian terhadap sebuah hasil rancangan diperlukan untuk menjamin bahwa hasil rancangan tersebut dapat mengemban fungsinya sesuai dengan yang diinginkan pelanggan. Pada penelitian ini metode yang digunakan untuk menguji hasil rancangan adalah metode eksperimen, adapun tahapan pengujian seperti yang diperlihatkan dalam diagram alir pada Gambar 6.

\subsubsection{Persiapan Bahan dan Peralatan.}

Bahan yang digunakan dalam penelitian ini adalah bahan disc dari S45C, bentuk dan ukurannya seperti yang diperlihatkan dalam gambar 5 dan komposisi kimianya seperti yang ditampilkan pada tabel 2, sedangkan alat uji adalah mesin hasil rancangan seperti yang diperlihatkan dalam gambar 4.

\section{Specimen}

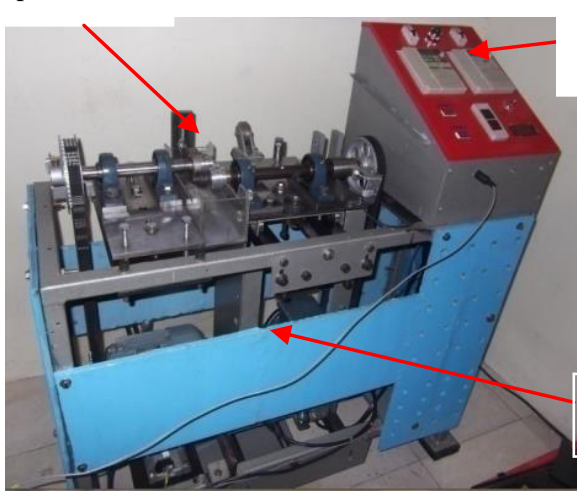

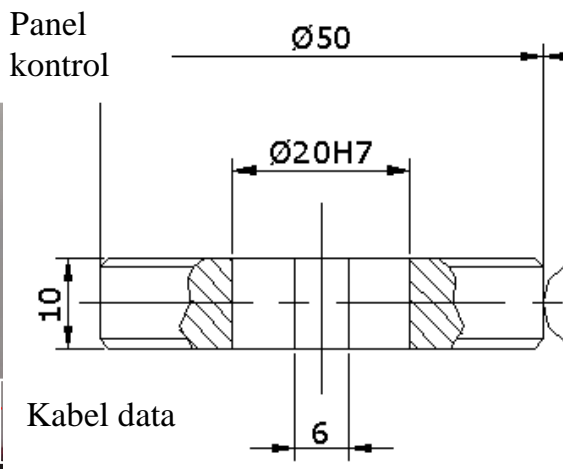

(a) $\emptyset 50$

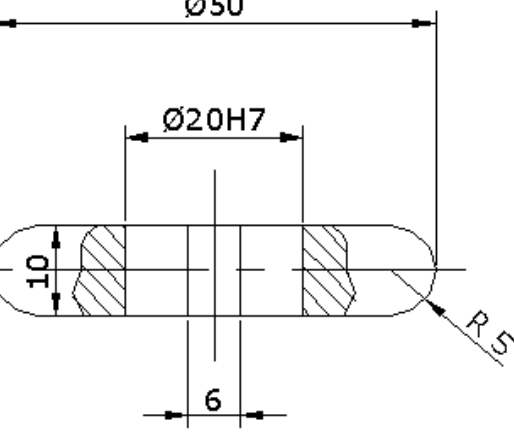

(b)

Gambar 4. Hasil rancangan disc test machine

Gambar 5. Benda uji berbentuk disc

Pada gambar 5 menunjukan disc (a) memiliki bentuk permukaan datar dan disc (b) memiliki permukaan berbentuk kurva. Bentuk demikian untuk menjamin kesejajaran permukan kontak dari kedua pasangan disc pada saat eksperimen [5].

Tabel 2. Komposisi kimia bahan S45C

\begin{tabular}{cccc}
\hline No. & Unsur kimia & Komposisi $(\%)$ & Kekerasan \\
\hline 1 & $\mathrm{Al}$ & 0.005 & \\
2 & $\mathrm{Si}$ & 0.142 & \\
3 & $\mathrm{Cu}$ & 0.23 & \\
4 & $\mathrm{Fe}$ & Balance & \\
5 & $\mathrm{Mn}$ & 1.585 & \\
6 & $\mathrm{Ni}$ & 0.116 & \\
7 & $\mathrm{C}$ & 0.474 & $66 \mathrm{HRA}$ \\
8 & $\mathrm{P}$ & 0.1 & \\
9 & $\mathrm{Cr}$ & 0.135 &
\end{tabular}




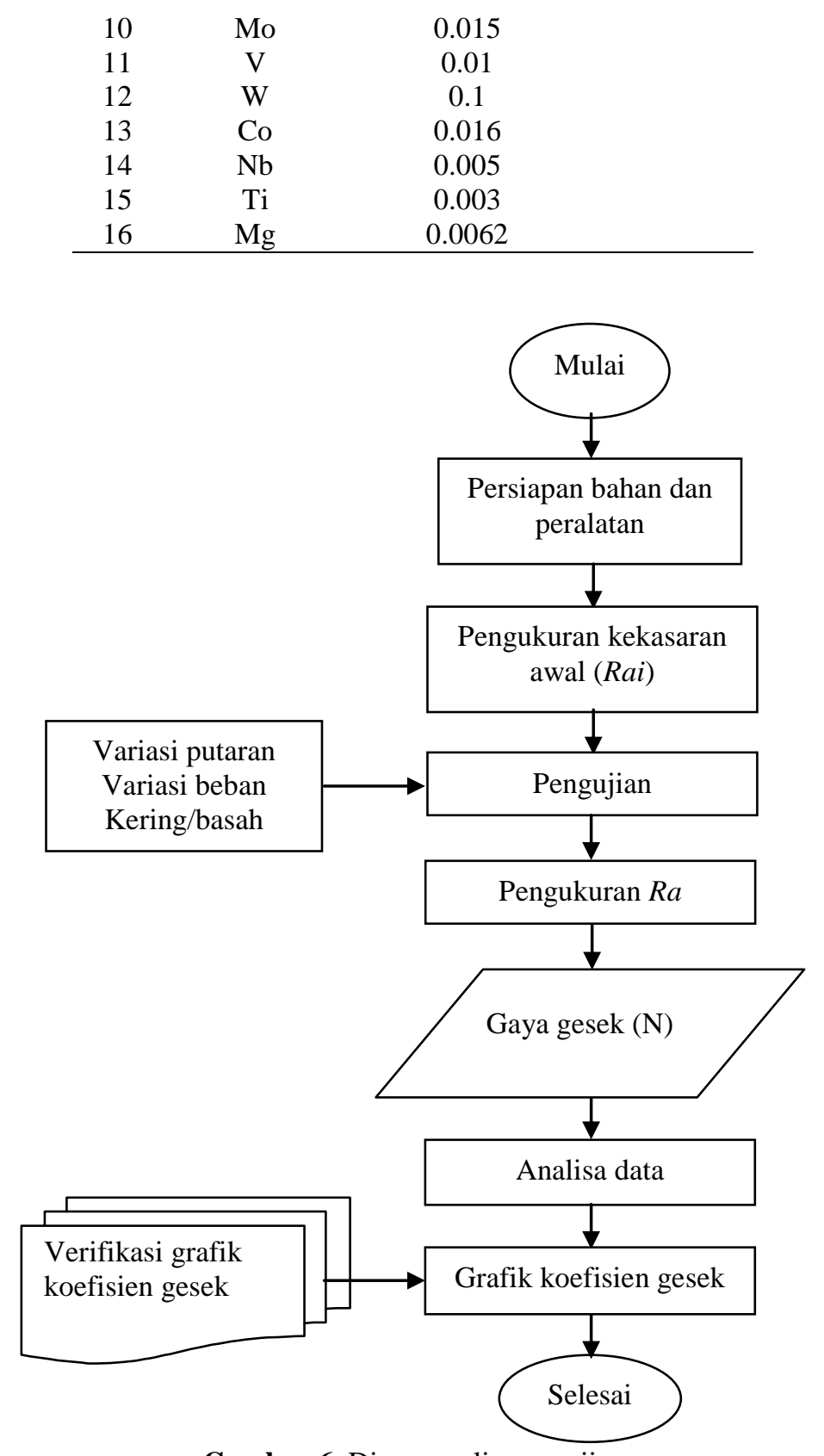

Gambar 6. Diagram alir pengujian

\subsubsection{Prosedur Pengujian.}

Prosedur pengujian mengikuti tahapan-tahapan sebagai berikut:

a. Mengukur kekasaran permukaan specimen.

b. Menentukan slip rasio dengan mengatur perbandingan jumlah putaran melalui kontrol panel. Slip rasio dapat dihitung dengan persamaan:

$$
S_{r}=\frac{2\left(V_{1}-V_{2}\right)}{V_{2}+V_{2}} \cdot 100 \%
$$

dimana: $\quad V=$ Kecepatan tangensial permukaan kontak.

c. Mengatur beban tekan $\left(F_{N}\right)$.

d. Menentukan besarnya gaya gesek $\left(F_{G}\right)$ berdasarkan dimensi mekanisme mesin uji. Persamaan gaya geseknya adalah:

$$
F_{G}=\frac{F_{c} \cdot 250}{d_{S}}
$$


dimana: $\quad F_{C}=$ Gaya yang terbaca pada load cell (gram).

$d_{s}=$ Diameter specimen $(\mathrm{mm})$.

e. Menghitung nilai koefisien gesek kinetik $\left(\mu_{k}\right)$, persamaan koefisien gesek adalah:

$$
\mu_{k}=\frac{F_{G}}{F_{N}}
$$

\section{HASIL DAN PEMBAHASAN}

Pelaksanaan eksperimen pada proses pengujian mesin hasil rancangan dengan menetapkan beberapa kondisi pengujian seperti:

Jumlah putaran specimen $\left(\mathrm{n}_{1}\right)=150 \mathrm{rpm}$ dan $\left(\mathrm{n}_{2}\right)=100 \mathrm{rpm}$, dengan slip rasio $40 \%$.

Beban tekan pada specimen $\left(F_{N}\right)=4 \mathrm{~kg}$.

Kondisi pengujian pada kedua permukaan kontak diberi pelumas pertamina, Prima XP $20 \mathrm{~W} 40$.

Rentang waktu pengujian selama 30 menit dengan durasi setiap pengujian dilakukan selama 5 menit.

Dari hasil pengujian tersebut diperoleh bentuk grafik yang merupakan fungsi matematik antara koefisien gesek dengan lama waktu pengujian sebagai berikut:

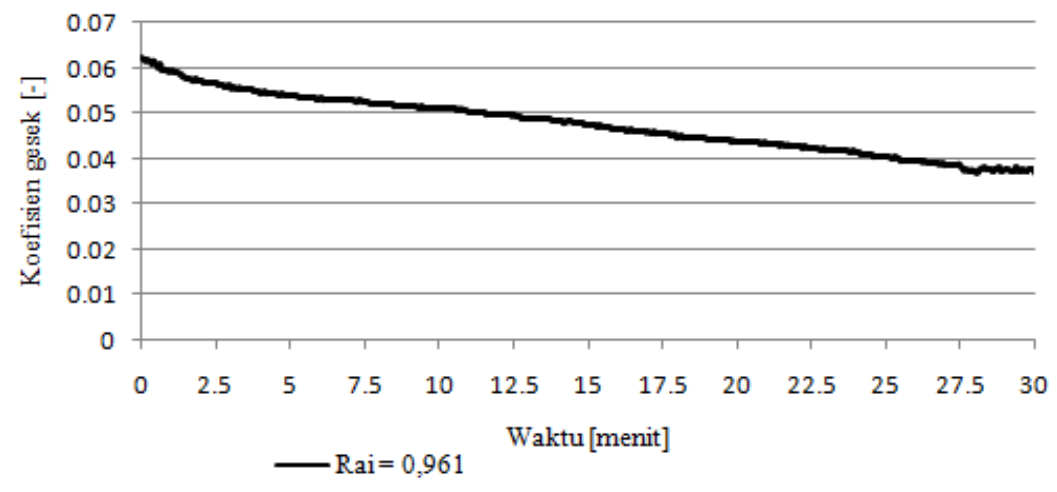

Gambar 7. Koefisien gesek pada saat running-in disc

Grafik hubungan antara koefisien gesek terhadap waktu running-in di atas menunjukan bahwa koefisien gesek cenderung menurun dengan berjalannya waktu pengujian dan kurang lebih pada menit ke 25 menuju menit ke 30 kondisi koefisien gesek menjadi stady state.

\section{KESIMPULAN}

Berdasarkan hasil eksperimen yang dilakukan pada mesin hasil rancangan maka dapat ditarik beberapa kesimpulan sebagai berikut:

a. Mesin hasil rancangan dapat digunakan untuk menguji specimen dengan ukuran diameter minimal $35 \mathrm{~mm}$ dan maksimal $100 \mathrm{~mm}$ pada putaran yang dapat divariasikan mulai dari nol sampai dengan $2800 \mathrm{rpm}$.

b. Mesin uji ini terbagi dalam 3 bagian utama yaitu mesin tribometer, analog digital converter, komputer pengendali (shoftware LabVIEW). Hasil data yang ditampilkan dari pengujian adalah gaya gesek $\left(F_{G}\right)$ dan koefisien gesek $\left(\mu_{k}\right)$.

c. Hasil pengujian memperlihatkan bahwa pada pasangan baja-baja ada kecenderungan penurunan koefisien gesek mulai dari 0,06 sampai dengan 0,04 seiring dengan menurunnya gaya gesek. Selanjutnya kondisi koefisien gesek menjadi steady state.

\section{DAFTAR PUSTAKA.}

[1] Kanavalli, B., 2006, "Application of user defined subroutine UMESHMOTION in ABAQUS for simulating dry rolling/sliding wear", Master Thesis, Royal Institute of Technology (KTH), Stockholm, Sweden.

[2] Harsokoesoemo, D.H., 2004, "Pengantar PerancanganTeknik", $2^{\text {nd }}$, Departemen Teknik Mesin, Institut Teknologi Bandung.

[3] Sularso, 2004, "Elemen Mesin”, PT. Pradya Paramita, Jakarta.

[4] Jeffrey, T., Jim, K., 2006, "LabVIEW for Everyone", 3 nd. United States.

[5] Hegadekatte, V., Kurzenha“user, S., Huber, N., Kraft, O., 2008 "A Predictive Modeling Scheme for Wear in Tribometers", Tribology International, 41, 1020-1031.

[6] Albano, L.D., 1999, "Engineering design”, Mechanical Engineering Handbook, ed Nam, P. Suh, Massachusetts Institute of Technology, Boca Roton: CRC Press LLC. 
[7] Samuel, A., Weir, J., 1999, “Introduction to Engineering Design”, Elsevier Science \& Technology Books, ISBN: 0750642823, Melbourne.

[8] Jamari, 2006, "Running-in of Rolling Contacts", PhD Thesis, University of Twente, Enschede, The Netherlands.

[9] Seyyed, K., 2005, "Engineering design process", in Mechanical Engineering from MIT and is currently a professor of engineering at Diablo valley college in Pleasant Hill, California.

[10] Wang, W., Wong, P.L., Zhang, Z., 2000, "Experimental study of the real time change in surface roughness during running-in for PEHL contacts", Wear 244, pp. 140-146. 